Meta

Journal des traducteurs

Translators' Journal

\title{
Lost in Translation: Shop Signs in Jordan
}

\section{Aladdin Al-Kharabsheh, Bakri Al-Azzam et Marwan M. Obeidat}

Volume 53, numéro 3, septembre 2008

URI : https://id.erudit.org/iderudit/019255ar

DOI : https://doi.org/10.7202/019255ar

Aller au sommaire du numéro

\section{Éditeur(s)}

Les Presses de l'Université de Montréal

\section{ISSN}

0026-0452 (imprimé)

1492-1421 (numérique)

Découvrir la revue

Citer cette note

Al-Kharabsheh, A., Al-Azzam, B. \& Obeidat, M. M. (2008). Lost in Translation: Shop Signs in Jordan. Meta, 53(3), 717-727. https://doi.org/10.7202/019255ar

\section{Résumé de l'article}

Les panneaux de magasins, nombreux dans le contexte commercial public en Jordanie, ont été largement étudiés d'un point de vue linguistique, sociolinguistique et pragmatique, mais jamais ils n’ont été abordés sur le plan de leur traduction. Cette étude, la première de son genre, aborde les problèmes et insuffisances liés au sujet en question. Les panneaux commerciaux ont été sélectionnés à partir d'un certain nombre de paramètres hétérogènes. Quant aux erreurs de traduction commises par les interlocuteurs, elles ont été empiriquement analysées et classées par catégorie. Étant donné que la langue et la culture sont inextricablement liées, le lien entre elles s'avère encore plus évident lorsqu'il s'agit des panneaux commerciaux locaux. Le sujet a été ainsi abordé en raison de son rapport direct avec la traduction de ces signes. Cette recherche met donc l'accent sur les facteurs à la fois linguistiques (e.g. l'ordre des mots, les choix lexicaux, les stratégies réductionnistes) et extralinguistiques (e.g. facteurs socioculturels et promotionnels) qui ont été à l'origine de l'inexactitude et l'inadéquation de la traduction, d'une part, et du détournement de l'information, d'autre part. Ce qui mène, en conséquence, à de graves problèmes sémantico-conceptuels sur le plan des traductions en question. Cette étude pourrait, d'une certaine manière, fournir un aperçu instruit des différentes tendances de traduction pratiquées dans le domaine ainsi que de la manière dont les panneaux commerciaux sont souvent exprimés, malmenés et, notamment, mal traduits.
Tous droits réservés @ Les Presses de l’Université de Montréal, 2008
Ce document est protégé par la loi sur le droit d'auteur. L’utilisation des services d'Érudit (y compris la reproduction) est assujettie à sa politique d'utilisation que vous pouvez consulter en ligne.

https://apropos.erudit.org/fr/usagers/politique-dutilisation/ 


\section{BLOC-NOTES}

\section{Lost in Translation: Shop Signs in Jordan}

\section{RÉSUMÉ}

Les panneaux de magasins, nombreux dans le contexte commercial public en Jordanie, ont été largement étudiés d'un point de vue linguistique, sociolinguistique et pragmatique, mais jamais ils n'ont été abordés sur le plan de leur traduction. Cette étude, la première de son genre, aborde les problèmes et insuffisances liés au sujet en question. Les panneaux commerciaux ont été sélectionnés à partir d'un certain nombre de paramètres hétérogènes. Quant aux erreurs de traduction commises par les interlocuteurs, elles ont été empiriquement analysées et classées par catégorie. Étant donné que la langue et la culture sont inextricablement liées, le lien entre elles s'avère encore plus évident lorsqu'il s'agit des panneaux commerciaux locaux. Le sujet a été ainsi abordé en raison de son rapport direct avec la traduction de ces signes. Cette recherche met donc l'accent sur les facteurs à la fois linguistiques (e.g. l'ordre des mots, les choix lexicaux, les stratégies réductionnistes) et extralinguistiques (e.g. facteurs socioculturels et promotionnels) qui ont été à l'origine de l'inexactitude et l'inadéquation de la traduction, d'une part, et du détournement de l'information, d'autre part. Ce qui mène, en conséquence, à de graves problèmes sémantico-conceptuels sur le plan des traductions en question. Cette étude pourrait, d'une certaine manière, fournir un aperçu instruit des différentes tendances de traduction pratiquées dans le domaine ainsi que de la manière dont les panneaux commerciaux sont souvent exprimés, malmenés et, notamment, mal traduits.

\section{ABSTRACT}

Shop signs, in the Jordanian public commercial environment, have invariably been studied from linguistic, sociolinguistic, and pragmatic perspectives, but they have been utterly ignored from a translational point of view. This study, the first of its kind, investigates various problems and inadequacies pertinent to the subject under discussion. Shop signs are selected here from a number of heterogeneous cities, and the translation errors therein, committed by communicators, were empirically analyzed and categorized. Language and culture are, of necessity, inextricably intertwined, and this nexus is particularly apparent in the world of local commercial shop signs, and thus it has been tackled for its direct relevance to the translation of these signs. This investigation, therefore, highlights the linguistic (e.g., word-order, wrong lexical choice, and reductionist strategies), and extralinguistic (i.e., sociocultural and promotional) factors that have turned out to lead to translation inappropriateness and unparallelisms, information skewing, and, consequently, serious semantic-conceptual problems in the produced TLTs. This study may, in a way, provide educated insight into the trendiest translation practices in this field, and the way shop signs are most often verbalized, mishandled, and mistranslated.

\section{MOTS-CLÉS/KEYWORDS}

shop signs, translation equivalence, practices of commercial translation, information skewing, sociocultural factors

\section{Introduction}

One of the components of a "linguistic landscape" (Landry and Bourhis 1997; Ben-Rafael et al. 2006) that marks a public space in a given territory is the shop sign. Shop signs, which can be viewed as pragmatic texts, represent an increasingly interesting genre, whose complexity may very well increase with the advent of new technologies. In order for us to consider shop signs as a genre, we should consider their sociocultural aspects. Wallace (1987: 30) deems genres to be "social events." She suggests that the term "genre" has more recently been extended to embrace "the whole range of culturally recognizable types of language activity," which include shop signs. Swales (1990: 53) elaborates, on the other hand, that genre can be "communicative events which are socioculturally recognizable." This conception reflects a new trend in genre analysis, which focuses on social purpose, and which differentiates as well genre from the notion of "register." We may, therefore, be able to describe shop signs as a register, but according to many this label falls short of acknowledging the key sociocultural constituents, of which one is of utmost significance because it is marked by "culturally recognizable language" (Wallace 1987: 32); that is, language from which one can easily recognize a given text as a shop sign. In translation, our sociocultural knowledge, especially that pertinent to the target language and culture, is being called upon more than ever to warrant the delivery of a corresponding shop sign. In other words, translators should not only engage themselves in identifying and interpreting certain facts about the information conveyed in a shop sign discourse, but they should also "be aware of a range of different attitudes to them, even if we do not personally share those attitudes" (Wallace 1987: 37-38).

In this era of modernity and globalization, the language of shop signs is somewhat "loaded" and challenging, so it is not difficult to justify why 
one should study their discourse. Most people, with an interest in shop signs, would agree that its language often contrasts in style and grammar with conventional discursive usage (for a similar discussion made on the discourse of advertisements (see Gully 1996). Although the language of shop signs displays an individual style in much the same way as other forms of "environmental print" or "minimal texts" (Wallace 1987: 24 and 29 respectively) such advertising billboards, names of sites, buildings, places and institutions, road signs, personal visiting cards, as examples, should not be viewed as an abnormal form of other varieties of the language (Leech 1963: 257).

Considering the practical importance of shop signs among merchants in Jordan, it is important to note that this specific type of written genre has been ignored from a translational point of view. Therefore, this study draws its conceptual framework from a few sociolinguistic and linguisticpragmatic works on shop signs that originally started in 1988 and continued in 1994 \& 1996 respectively, and its research objectives from translation studies and sociolinguistics. The prevailing scope of the paper is, then, far narrower than the above statements may suggest. Rather than concerning ourselves with sociolinguistics or cultural studies per se, our focus is on a particular problem, namely the inadequacies and inappropriateness (if not incorrectness) of translating these signs. This paper presents an empirical study of the translation of shop signs in Jordan. Language and culture are, of necessity, inextricably intertwined, and this nexus is particularly apparent in the world of commercial shop signs. What we say in this regard should be compatible with various theoretical frameworks; it will not depend specifically on the cultural approaches alone, nor on the sociolinguistic approaches, but on a combination of all of this. We then proceed by investigating the translation of the written language, viz-a-viz shop signs in the public Jordanian commercial environment and how these signs reveal certain aspects of Jordanian culture and daily life. In this paper, shop signs are studied in a number of heterogeneous cities. The study focuses on the translation errors committed by those who attempt to relay the content of shop signs to English. It is our contention that the study of these shop signs, when taken as a whole within a given environment, outlines a field that may justify a systematic study, in and of itself, as it may constitute an intellectually intriguing way of uncovering trendiest translation practices.

A literature review has failed to locate any scholarly discussion on the translation of shop signs, as the main focus has been on the translation of advertisements (e.g. Shaker 1995; Pedro 1996; Defeng 1999 among others), a gap we, thus, hope to bridge. Zughoul (1988), for instance, addresses shop signs from a sociolinguistic, and cultural viewpoint, where he objects to the use of foreign elements in signs, and he regards such use as representing "aspects of cultural alienation," as his title suggests. On the basis of their employment of non-native European (predominantly English) words, and Roman letters, Zughoul (1988: 26-31) classifies shop signs in Jordan into six categories. Likewise, Salih and El-Yasin (1994) conduct a sociolinguistic study where they investigate the reasons behind the spread of foreign shop names and investigate people's attitudes towards foreign names. While, on the other hand, the most recent linguistic study, El-Yasin \& Mahadin (1996), focuses on the extent to which shop signs are spreading in Jordan and the function of language use in this particular context. In the authors' own words "our interest here is only in the linguistic aspects of signs: whether the words used are Arabic or foreign, whether they are written in Arabic or Roman script, and what they are intended to convey to consumers by way of promoting goods and services, i.e., what functions they serve." (Mahadin 1996: 408). Clearly, it is axiomatic that none of the aforementioned studies deals with shop signs from a translational point of view, a gap that this study hopes to fill.

Jordanian shop signs have several characteristics that make them translationally motivating and pedagogically appealing. First, they represent authentic material rather than texts prepared for the purposes of translating. This is organically related to the view that language use is a cultural act (see e.g. Kramsch 1993: 178). Second, Jordanian shop signs not only represent authentic materials, but also commonly encountered ones by anyone living in or visiting Jordan or simultaneously both. Thus the ability to read and understand these signs has considerable practical value. Third, each shop sign, however brief, represents a whole text in itself in consideration of its social and cultural contexts, not undervaluing the importance of non-linguistic elements such as pictures which have their own bearing on meaning. Finally, the shop sign material in question also has the advantage of being so varied that, in theory, it could be possible to compile a monolingual or even bilingual corpus that can stimulate many empirical translation studies down this path of thinking.

With the foregoing remarks in mind, we will assess the effectiveness and correctness of translation in maintaining the function and communicative-pragmatic effects of the SLTs, in a selection of Arabic commercial shop signs. The study of the structure and rhetoric of shop signs for translational purposes expectedly aims to find whether a translated version of a shop sign triggers effects on 
the target language audience equivalent, or similar, to those triggered by the source language shop sign on its own audience. Different scholars have addressed the concept of equivalence from various perspectives: formal (e.g. Catford 1965) dynamic (e.g. Nida and Taber 1969), lexical and textual (e.g. Baker 1992), and semiotic (e.g. Jakobson 1959). Discussing these different perspectives goes beyond the scope of this paper, and it suffices to point out that we employ the term equivalence in its general sense as to mean comparable or equal. The notion of maintaining equivalent effect in shop signs translated from Arabic into English, or vice versa, has not received due attention from translation scholars, translator trainers, and discourse analysts, let alone looking into the type of factors, i.e. linguistic, cognitive, or cultural, that contribute to achieving higher degrees of equivalence.

We will also attempt to identify the different interacting factors that impinge upon the translation of shop signs. Of particular interest to us are the ways where the translator fails to convey the intended message correctly and aptly; the ways where a supposed equivalent version may prove uneducatedly unintelligible to the translator, the ways where different cultures and mindsets may assist in or impede translation. Obviously, in translating a shop sign, the translator not only draws on his/her linguistic knowledge, but also on his/her cultural and social knowledge, especially when the shop sign in question is culturally bound. In the act of translating, such knowledge often draws on the structural and lexical import of the shop sign in question.

\section{Data}

Digital photography makes it relatively easy and convenient to compile a large electronic corpus of signs. This study is based on 165 digital photos of Jordanian shop signs, only a few of which can be seen in this paper for spatial limitations. The documentation of these was collected via digital cameras, and the data therein were stored on CDRom and USB Flash Drive files. These signs were, then, categorized using a coding system developed for this study. The parameters included effectiveness and adequacy of the relevant translations of these signs; order of appearance of the components making the shop sign in question. In order to represent the complexity of the "linguistic landscape," a distinction was made between a number of different domains according to types of services and areas of activity.

The digital photo sampling focused on three affluent cities: Amman (the capital), Irbid (one of the largest and densely populated cities in the north of Jordan), and Mafraq, in the east, all three cities that have prolific shop signs. That is where the major commercial activity takes place, and the principal public institutions are located. The data were categorized according to specific subareas of business activity, or to categories such as professional (legal, medical, consulting, private offices), commercial (subsequently according to branches such as food, clothing, furniture, houseware), and services (agencies like computer maintenance, mobile maintenance, translation, printing, photocopying). Among other variables we focused on was the very languages appearing on signs, their saliency, their order of appearance, and the like.

\section{Discussion}

In general, the analysis of the data has shown that, the relevant translations of the sample shop signs were error-ridden. The type of translation errors found varies along a continuum that proceeds from destructive orthographic errors to varying intolerable translation errors. Four main types of translation errors were identified: orthographic errors affecting the message, transliteration, translation errors and avoidance of translating via recoursing to total foreignization demonstrating ignorance at best. Each of these error types will be taken up in the preceding order.

\subsection{Orthographic-Translation Errors}

Two types of orthographic errors were isolated: simple errors that have little influence on the conveyed message, and serious errors that bring about radical changes in the TL versions. To exemplify the first type, observe the words coffee, gentleman, mobile in the following instances:
(1) Jannat az-zuhūr Paradays Flowers
(2) Mat'am 'Arabiyyāt sharki cofee shop
(3) Kufi Shop Senān Senān Coffe
(4) Saloon gentelman for men
(5) Gentel Man gentilman
(6) Diamond Mobil al-Masä' lil-Khalawiyyāt

The misspelt lexical item paradise, i.e., paradays in example 1 above clearly exhibits the degree of confusion in the produced TL version. Misspelling here does seem to result in a conceptual problem as the translation is less likely to communicate the idea of "flower paradise," which is being affirmed by the accompanying word flowers. Similarly, coffee represents one of the most repeatedly misspelt lexical items, which was found to have numerous erroneous variants as can be noticed in the sample 
examples 1 and 2. Likewise, the word gentleman is not only misspelt as is clear in 3, but it has also been split into two parts, as shown in 4 . Not different from all these examples is the word mobile misspelt in 5. What may account for the misspelling of these samples is that shop owners do not seem to have cared much to consult language specialists or translators for the matter, and, even worse, they have taken the task of writing these signs themselves. However, the misspelling in these cases has been found to have no impact on the message conveyed to the TL. Low degree of seriousness of these errors can account for why the TL equivalents appear to be intelligible, and serve their intended purpose.

The second type of spelling error seems, on the other hand, to have some serious effect on the translated shop signs. Misspelt words here not only have strayed from their intent, but have also caused some conceptual problems. To illustrate, consider the following examples:
(7) Ghassān Saloon Parpar for men
(8) Uni six Nash'at Boutique
(9) Miriland Mireland

In example 6, 'Ghassān Saloon' is written in Arabic, while its English equivalent "Parpar for men" attempts to convey the message embedded in the SLT, i.e., barber shop. Recently, it has been the norm in Arabic to choose a masculine proper name like the one in 6, i.e., 'Ghassān', rather than link it to the word salon to express the idea of a barbershop. This is one of the most common practices in translation in Jordan. Nevertheless, the communicator in charge of putting the Arabic shop sign into English persistently imposes the prepositional phrase 'for men,' which indicates that the communicator is unaware of the fact that the English word "barber" already implies the idea of 'for men.' Another reason that may explain this redundancy is the fact that the loan word "salon" can in Arabic indicate a hairdressing (or hair cut) shop for either men or ladies. The issue of redundancy will be discussed in depth later on. It seems difficult to someone who does not know Arabic, and who would have access only to the translated version, to figure out that Parpar here is written for "barber" unless extra mental processing effort is exerted. Nash'at Boutique in 7 has caused a translation problem by misspelling 'uni six' which is employed here to indicate that this boutique includes goods for both sexes. Being the only two words written in English on the shop sign, it is clear that it changed the TL version and caused a conceptual problem to non-native speakers of Arabic. The conceptual problem caused by the misspelt word
Merryland (as Mireland), which appears on a shop sign for women perfumes, makeup and accessories, is also serious enough to block envisaging the image and message intended by the SL word.

\subsection{Translation Errors}

Three types of translation errors were identified: word-order errors, terminological-conceptual errors, and informativity errors. The three types will be discussed in that chronological order.

\subsubsection{Word-order Translation Errors}

Word-order does play a significant role in translation as it can affect the way information is organized within any linguistic construction, be it a phrase, a compound, or a sentence. A characteristic feature of shop signs is that they are less likely to operate at the sentential level, and more likely to operate at the micro level, which includes words, phrases and compounds. Tampering with word order at the lexical-phraselogical level would inevitably lead to serious translation problems, as the following instances indicate:

(10) țuyūf Madinat al-kumbyūtar Spectrum City Computer

(11) dunyā l-malā'ika Planet Angel

(12) biṭākāt r-rahwanjī l-'ālamiyya Rahwanji Cards International

(13) hilwiyyāt 'abdel karìm 'affūrī wa'awlāduh Sweets Abed Al-Kareem Al Affory \& Sons

(14) markaz rana l-mustaqbal Center Rana Future

(15) al-bank al-'arabī l-islāmì d-dawlì Islamic International Arab Bank

Obviously, the above examples illustrate how the SL message is twisted when these examples were rendered into English. In 10, for instance, the wrong word-order considerably baffles the reader when one realizes that the SL shop sign in question precisely means 'Spectra of the Computer City.' By the same token, the word-order in Planet Angel in 11 is reversed and should be 'Angel Planet'; in 12, the constituent elements of the sign were mistakenly ordered as Rahwanji Cards International, instead of 'Rahwanjī International Cards'; in 13 Sweets Abed Al Karìm Al-'Affūrī \& Sons erroneously translated as to mean 'Abed Al Karim Al'Affürī \& His Sons Sweets'; in 14, Center Rana Future is a word-order that is supposed to relay the idea of 'Center of Future Rana'; and finally in example 15, Islamic International Arab Bank, the word-order imposed is presumed to yield the idea of Arab Islamic Bank International. The problem of the word-order in 11, 12 \& 15 might not be extremely serious in comparison to that in 10,13 
$\& 14$, in terms of damaging the overall message, but these are serious enough to mar and baffle "educated" clients. However, it was found that there are many cases which include wrong wordorder that have far more serious impact on the message to be translated as is illustrated in 10,13 , \& 14. Accordingly, it can be claimed that wordorder should not be undervalued or taken lightly in translation as it plays a key role in producing the right lexical links and relationships that would assist in delivering a correspondingly equivalent message in the TL.

\subsubsection{Terminological-Conceptual Errors}

What we mean by a terminological-conceptual error is one caused by a wrong lexical choice, which, in turn, gives rise to a distorted and unintelligible message in the TL version. In other terms, a terminological error brings about a drastic change or deviation in the semantics, or conceptual template of the shop sign in the TL. Thus, improper terminological decisions do appear to have a great effect on the conceptual integrity and precision of the delivered translation. The analysis of data has revealed that this category is the most common and predominant among the rest. The type of lexicalterminological errors encountered here results in sharp differences between the source language and receptor one, to the point of conceptually derailing from the originally intended meaning. In fact, the problems analyzed were too varied to classify them into groups and subgroups. Therefore, we will present as much as we think is representative enough of this broad type. Let us consider the following as examples:

(16) markaz l-muhtarifūn lit-tașwīr wal-muntāj The Professional Shoot Studio \& Labs

(17) al-mukhtabarāt t-țibbya t-takhaṣuṣyya Consulting Medical LABs

(18) bashä'ir lil-'ittiṣālāt d-dawliyya Bashair International Calling Phone

(19) al-ma'ānì lit-tuhaf sh-sharqiyya wal-arāqīl Al-Ma'āni For Eastern Masterpieces \& Narghiles

(20) istirāhat mishwār Mishwar Rest

A thorough look at the above examples reveals that a sole lexical item can sometimes ruin the overall intended message of the shop sign. This vulnerability might be accounted for by the fact that shop signs are normally encapsulated in short linguistic structures; that is, their structures do not exceed that of words, phrases, and compounds. This linguistic property makes each word enjoy a greater semantic status than it would have in other larger structures. In 16 above, for example, the commu- nicator erroneously employs shoot instead of shot or even shotting. It is clear from the co-text (Studio and Labs) that this shop provides a photo service, and that's why the choice has rested with shoot to express the idea of shotting. However, even the word shotting might not be highly precise as it connotes filming in English, which is quite different from what the communicator is trying to convey, i.e., photographing. Similarly, the TLT produced in 17 triggers a serious semantic problem, owing to the terminological error consulting, which is actually too far away from delivering what was originally meant, i.e., specialist medical labs. Examples $18,19 \& 20$ are also striking cases that may reveal the degree of perplexity in the supposedly equivalent TLTs.

Comparing SLT in 18 with its TLT, it proves to be apparent that the translation has failed to yield the message embodied in Arabic as a result of collocating calling with phone. Terminologically, calling phone should be substituted by calls alone. A better translation might run as long-distance calls. The micro-level havoc is also self-evident in example 19 where the word masterpieces is wrongly used to mean artifacts, and narghile is an archaic word unconsciously employed instead of the known term hubble-bubble. And the message seems to be completely blurred in 20 in which the communicator produces an inept TL version as a result of using an inappropriate lexical item, i.e., rest, to express the idea that this is a place where one can stop to have a break. Indeed, the Arabic word istiräha, for which the equivalent rest was produced, can mean different things in different contexts. In one context, it may mean rest; in another, it may mean break; and, in a third, it may mean motorway service. An optimal translation that can be suggested here is 'Mishwar have a break'

The data analysis has also shown that some cases have been found to indicate that new meanings emerge constantly due to pure socio-cultural interacting factors. A corollary of this, is the existence of particular commercial words and/or terms that have recently been assigned multiple, novel senses, and consequently, are understood differently by different shop owners, communicators, and clients. To exemplify more on this point, let us consider the Arabic word sborät, which appears on a variety of shop signs connoting different meanings. Observe the following examples:
(21) isborāt l-Muhtasib Al Mohtaseb Sport (Adidas, Reebok, Nike, Puma)
(22) Cubāry sborāt sittātī Cobary
(23) al-Krawn albisa jāhiza Al-Karawān Spore 


\section{(24) isborāt rijjālyya Bonito}

In 21 above, the Arabic text which reads isboät Al Mohtasib, the word isborāt is translated as "sport," and what the communicator actually means here is "sports wear," and in 22 that reads Cobary isborät sittāt $\bar{t}$, the word suggests two clashing senses as the accompanying images reveal. The right-hand side of the sign features an accompanying photo of a girl wearing the formal, whereas the left-hand side features another photo for a girl wearing the casual. Thus, this shop includes both causal and formal wear as the word signifies. But the situation is entirely different in 23 as the communicator chooses the English word spore to mean isborät and then translates it into Arabic as ready wears (albisa jāhiza). Whereas in the last example (24), which reads Bonito isborāt rijjāliyya, the word is left untranslated, landing the mission of figuring out its meaning with the client, a matter that displays rife semantic indeterminacy.

The next category includes cases that counteract what has already been discussed above. By drawing on the existing Jordanian sociocultural framework, these cases occasion a specific English lexical item, which has unanimously been chosen to stand as a translation for another specific word in Arabic. This semantic determinacy does not seem to go too far in achieving the required results, as the link made between the two lexical items is undoubtedly awkward; that is, the Arabic lexical item does not match with its agreed upon English counterpart. To illustrate this point, observe the following instances:

\section{(25) lu'lu'a lil it-tiṣālāt Pearl Link \\ (26) sarāb link lil it-tisāāāt Sarab Link \\ (27) vinus link Venus Link}

The above examples show that the lexical item link, as a transliterated or borrowed form, is mainly used to mean ittisālāt (lit. communications), which pragmatically means 'mobile phone shop.' The reason why there is such an association between link and its new counterpart mobile phone shop might be ascribed to the idea that mobile phones link or connect people together or bring them closer to each other. Therefore, in the Jordanian culture nowadays, this term is semantically established to give such a sense, and so the mere mention of the word link in almost any context would automatically trigger the idea of a "shop selling or maintaining mobile handsets." Interestingly, it is even odd in Jordan to come across a sign for a mobile phone shop without seeing the word link as a key element in the sign's fabric, and which hap- pens to appear in the boldtype and/or the upper case script.

Another supportive case is that which involves the English word show (ma'rad), which has been used to express that the shop sign is spacious and all-inclusive as the following examples reveal:

(28) ma'rad sh-Shūha Shūha show

(29) al-Ma'rad l-Māsī Diamond show

(30) ma'rad barakāt Barakāt Show Room

(31) ma'rad abū nāyel Abū Nāyel Wears Show Room

Conspicuously, the communicator, in the above cases, produced TLTs which are hardly to get the messages across to the TL audience. Indeed, it is not uncommon to see that some shop signs utilize the words show and room show to communicate the idea of big shop, i.e., store. The wrong lexical choice here not only fails to relay the intended message, but also causes a conceptual problem. Show or show room are always associated with movies and plays, a fact alludes to how this lexical choice is too far from constructing an equivalent TL version. To say the least, examples 28-31 above constitute only a representative sample of a predominant type of terminological-conceptual errors, which is unavoidably bound to have a formidable, unfavourable bearing on the sought meaning.

So, all these examples (21-31) lend further credence to the view that the meanings we derive from texts are largely socioculturally determined. In this way, the social framework within which a shop sign resides should not be viewed only as a key component in our interpretation of the message of the shop sign in hand, but also as a key component for the success of its translation. The clients must "draw on different levels of contextual knowledge to interpret them" (Wallace 1987: 29). Shop signs, as we can see, prove to be one of the most prominent cultural-specific forms of discourse.

The last category, which was found to offer conceptual problems, involves cases where there is no necessary relationship between the source shop sign and its TL equivalent. The supposed translation not only displays blatant semantic deviation from the intended meaning, but also introduces an entirely different message to the target clients. This type of error may at best exhibit ignorance. Observe the following examples:
(32) șalon l-wasāma Ladies Kids Saloon
(33) al-mashriq lis-sāâat Westar
(34) alf-yā'l-mi'mār A-Z Home Arts 
(35) al-muhtarifūn li-șināat l-lawhāt l-i'lāniyya Pro Digital Printing Service

One would immediately realize the extent to which the above translations slanted from their SLTs, especially if we compare them to what the TLTs attempted to convey in Arabic. Observe how in example 32, Ladies Kids Saloon is yielded as an equivalent translation for "Smartness Salon"; Westar as an equivalent for "The Orient/Levant for Watches"; and, A-Z Home Arts for A-Z al-Mi'mār where al-Mi'mär is a proper name which means the builder and Arts is erroneously used to mean furniture, that is, the communicator attempted to metaphorically play on the meaning of the proper name as to communicate the idea that this shop can build your house from $A-Z$. However, if we look closer at this case, we realize that the source shop sign text included other linguistic material that has been ignored in translation and which is of paramount importance as to understand the metaphor imposed there. The dropped linguistic material includes lexical items such as "doors," "kitchens," "closets and cupboards," etc. It is clear at this point that the communicator basically attempted to convey the idea that we provide all sorts of furniture through which we build your house. It is also evident that target version failed to retain the metaphor, and to effect such conceptual depth.

And the last example (35) provides a striking instance on the severed ties between the SLT and TLT. A sound translation of 35 would be something like "The Professionals for Advertising Boards," not Pro Digital Printing Service. It may be possible to observe here the intolerable and deplorable derailment which makes the translation stand as irrelevant, and misrepresenting. It is, by no means, that pro is an abbreviation that stands for professional and digital, printing and service above are absolutely improper and counterproductive. Based on all these examples (32-35), it can be concluded that some translations seem to show no necessary interrelationships with their TLTs, a fact that may reflect the lines of thinking pertinent to English and marketing; that is, communicators sometimes seem to find it quite acceptable to employ foreign words (heavily English ones), irrespective of how accurate and communicative their translations are.

\subsubsection{Reductionist Translation: Informativity Errors}

In this class of examples, we encounter cases where the shop sign includes a partial translation for the message in TL. The communicator here adopts a reductionist approach where, half or more than half, of the message is left untranslated. In this type, spatial considerations seem not to come into play with such reality. The sort of the reductionist translation operative here should not be visualized as being a functionally economical, one; rather, it should be visualized as a translation effecting a devastating economicality that is geared to sacrifice many bits of the message, and which, in turn, results in a considerably less informative target version. Observe the following examples:

(36) al-muktashifūn li-'ajhizat l-kumbyūtar Discovery

(37) al-muz'ij link Mobile

(38) farawla lil-ahthiya Strawberry

(39) al-maghrabī. Albisa sittātī bannātī wallādī Al-Maghrabi Wears

A scrutinizing look at the above examples reveals the sizable discrepancy between the SLT and its counterpart translation. In 36, computer discoverers is erroneously translated by the target version discovery, which not only perplexes the client with its wrong derivative, but also causes a big semantic loss upon dropping the word computer out; in 37 , the naughty for mobile phones (link) is reduced into one lexical item, i.e. mobile. Example 38 provides a funny case as the communicator translated the proper name itself and left the most important word unrendered. The proper name Farawla happens to be a fruit, that is, strawberry, a reason which may explain why it has been translated into English literally. And the other lexical item lil-ahthiya, i.e., for shoes, has been left out. Having only the word strawberry on a shoes shop is undoubtedly bewildering to any client. In the last example of this group, the translation finds it sufficient to provide the hyponym wear and drops out the other detailing lexical items which specify the type of wears sold there, i.e., sittäti (ladies), bannàtī (girls), and wallādì (kids). From the examples above, it is obvious that the delivered TLTs appear to feature much less informativity than their SLTs, owing to a deliberate expunging or reductionist strategy followed by the communicators.

The reason why communicators opt for choosing one lexical item as to stand for the whole sign might be driven by their business intuitions and prospects, that is, they may find it plausible to concentrate on very limited lexical items as to draw clients' attention to the message contained in these selected items. Another explanation might be connected to sociocultural conception about English as one of the most internationally prestigious languages and so what matters is to use any English, which can indicate that the communicator is with it. Accordingly, it might be, in a way, claimed that Jordanian clients have better attitudes towards signs in both Arabic and English compared to signs only in Arabic. 


\subsection{Transliteration Replacing Translation}

Transliteration can be one of the reliable strategies of translation, especially when faced with a specific lexical item that has never been lexicalized in the TL. Apart from problems of lexicalization, transliteration can also be indispensable when it comes to transferring foreign proper names that are normally never meant to be translated. But, when transliteration exceeds these parameters, it must have a function or must reflect a new trend in the translation industry. The data analysis has revealed that transliteration is not only used to resolve lexicalization problems and proper names; rather, it is heavily employed with lexicalized and established items. In other words, transliteration is seen everywhere in Jordan as one way of communicating the message. This situation recalls the earlier discussion which stressed that people hold English in high regard and its use on shops sign can result in a better consumer attitude towards shopping, and thus the sole concern of the communicator becomes associated with showing the English characters in any format, without caring at all about communicating the message to foreigners. Therefore, it can be posited that transliteration is a monolingual activity aimed at demonstrating that the shop owner in question is keeping abreast with modernity, a factor thought to affect attitudes and subsequently to boost sales.

Three subtypes of transliteration problems were identified: total transliteration, partial transliteration, and half transliteration, and half translation. Let us take some examples to illustrate these one by one. Consider the following for the first type:
(40) City Rose citī roaz
(41) orbit internet Café orbit internet kāfei
(42) Royal Fashion royal fäshin
(43) Top Snack tup snāk
(44) Relax Music rilāks myūzik

The strategy followed here is to write the commercial shop sign completely in English and then to transliterate this into Arabic using Arabic characters. So, the English segment is never translated here. The second subtype displays partial transliteration of foreign English elements, which do not surface on the SLT, as it is clear in the following two examples:

(45) mahallāt hāi lāyif

(46) nyühoam lil-mafrūshāt
Each of these two examples (45 and 46) contains one word in Arabic and another in English, and transliteration takes place with the English one, i.e., "hi life" and "New Home," respectively.

The third subtype is concerned with having a shop sign which displays the two opposing linguistic codes (Arabic and English), where the English lexical item(s) is/are transliterated and the rest are translated, or vice versa. Observe the following sample examples:
(47) matba'it sh-sha'ib
Al Sha'ib Press
(48) Prince butīk
(49) șaydaliyyat l-wașat Al-Wașat Pharmacy
(50) șabāyā snāk

In 47 above, the first lexical item mitba' $a$ is properly translated into press, while the second one ash-sha'ib (i.e., people) is simply transliterated. Perhaps the communicator was confused over which equivalent to go for as the word can be translated by a variety of options in English. Considering 48, one may notice that the English word prince is maintained as it is and the second (i.e. boutique) is transliterated. Indeed, the transliterated form of boutique has been assimilated in Arabic and is no longer considered as such due to a lexicalization process it had undergone. Example 49 represents a peculiar phenomenon that has to do with pharmacy shop sign. The analysis has shown that every single pharmacy shop sign maintains the word pharmacy as an accurate equivalent for its Arabic counterpart saydaliyya, whereas the rest of the linguistic material is just transliterated. This strategy could be ascribed to certain cultural factors that have to do with visiting tourists who should be able to discern pharmacy shops in emergency situations. Example 50 resembles 47 in the sense that one item is translated and the other is put in Arabic. Whereas the first lexical item was translated in 47, it is not so here, as it is appears in Arabic and the second (snack) is transliterated. At this juncture, it can be said that there are no rigid rules to govern the heavy use of transliteration. In general, this may be explained by the tendency to keep the English flavour and to maintain the element of "Englishness." Transliteration might be looked at, by communicators, as a tool that is much more powerful than translation in bringing in prestige and exoticism.

\subsection{Total Avoidance via Foreignization}

Total avoidance of translation, and verbalizing the message of the shop sign in a foreign language, i.e., English, is the least common strategy that shop owners opted for in order to promote their shops. 
The choice of this strategy can be attributed to the following reasons. First, shop owners could have thought, to the best of their knowledge, that the target language, i.e., Arabic, lacks corresponding equivalents. Another reason is that shop owners or communicators may have found it so challenging to translate them. A third reason could be that some trademarks are worldwide recognized and this exempted the communicator from struggling with translating, which may be viewed, in such a situation, as an activity that may affect the marketing power of the message. More importantly, shop owners may have decided to resort to a foreign language and completely exclude their own tongue, as to show the highest degree of prestige. For the illustration of this, consider the following examples:

(51) Sweety Jeans

(52) Four Seasons

(53) Your Gift Cosmetics

(54) Bata

The first three examples (51-54) substantiate the thoughts that these signs may not have corresponding equivalents in the TL, or the communicator's inability to relay the message equivalently. Indeed, we believe that the strongest reason to have motivated the communicator to use pure English is the one relevant to the sociocultural perspective, which ranks English as the most prestigious foreign language in a country that fell under the British mandate one day. Different from all other examples in this category, Bata in 54 is a remarkably wellknown brand and this makes its translation unnecessary if not redundant. This example supports the point that translating internationally acknowledged brands may discharge the shop sign in question from its communicative, promotional power.

\section{Conclusion}

This study has investigated various types of problems and errors associated with translating shop signs into English. These can be projected along a continuum that proceeds from simple orthographic errors to varying degrees of awkward and intolerable translation errors. The discussion has shown that shop signs in Jordan are translationally errorridden, owing to a variety of linguistic and extralinguistic factors that were highlighted in the course of this paper. The linguistic factors involve word-order, wrong lexical choice, and reductionist strategies which have proved to result in information 'skewing,' and consequently giving rise to serious semantic-conceptual problems. Equally, the extra-linguistic side, involves a variety of sociocultural and promotional factors that have been found to have a great impact on the way shop signs are verbalized. Indeed, the ensuing discussion has attempted to bring to the light that in some shop signs there is no relationship between the SLT and its supposed TL equivalent. In fact, the existence of the TLT in such cases was incidental to the communication act. Other cases revealed that the translation was crucially dependent on the SLT, and this seemed to be a prevalent case in some signs referred to in this study.

Aladdin Al-Kharabsheh,
BAKri Al-Azzam
and Marwan M. Obeidat
The Hashemite University, Zarqa, Jordan
ala74@hu.edu.jo

\section{REFERENCES}

BAKER, M. (1992): In Other Words: A Coursebook on Translation, London and New York, Routledge.

Ben-RAFAel, E. et al. (2006): "Linguistic Landscape as Symbolic Construction of the Public Space: The Case of Israel," International Journal of Multilingualism 3-1, pp. 7-30.

Catford, J. (1965): A Linguistic Theory of Translation, London, Oxford University Press.

Defeng, L. (1999): “The Teaching of Commercial Translation in Hong Kong: Problems and Perspectives," Babel 45-3, pp. 193-204.

El-Yasin, M. and R. Mahadin (1996): “On the Pragmatics of Shop Signs in Jordan," Journal of Pragmatics 26, pp. 407-416.

Gully, A. (1996): "The discourse of Arabic Advertising: Preliminary Investigations," Journal of Arabic and Islamic studies 1, pp. 1-49.

Jakobson, R. (1959): “On Linguistic Aspects of Translation," in Brower, R. A. (ed.). On Translation, Cambridge, Harvard University Press, pp. 232-239.

Kramsch, C. (1993). Context and Culture in Language Teaching, Oxford, Oxford University Press.

LANDRY, R. and R. Bourhis (1997). "Linguistic Landscape and Ethnolinguistic Vitality: An Empirical Study," Journal of Language and Social Psychology 16-1, pp. 23-49.

LeEch, G. (1963): "Distinctive Grammar in British Television Advertising," Studia Neophilologica 35-2, pp. 256-264.

NidA, E. and C. TABer (1969): The Theory and Practice of Translation, Leiden, E. J. Brill.

Pedro, R. (1996): "Beyond the Words: The Translation of Television Adverts," Babel 42-1, pp. 2745.

SAlih, M. and M. El-Yasin (1994): “The Spread of Foreign business names in Jordan: A Sociolinguistic Perspective," Abhath Al-Yarmouk 12-2, pp. 37-50.

ShakiR, A. (1995): "The Translation of Advertisements: Registeral and Schematic Constraints," Meta 40-1, pp. 62-72. 
Sidiropoulou, M. (1998): "Advertising in translation: English vs. Greek.” Meta 43-2, pp. 1-14.

Wallace, C. (1987): Reading. Language Teaching: A Scheme for Teaching Education Series, Oxford, University Press.

Zughoul, M. (1988): “Al-lāfitātu fil-'urdunni: dirāsatun lughawiyatun 'ijtimā'iyyatun liba‘ đ̣i jawānibi ghurbatinā l-ḥaḍāriyya (Signs in Jordan: A Sociolinguistic Study of Some Aspects of our Cultural Alienation)," in The Jordanian Academy of Arabic and the Arabic Department at the University of Jordan, eds., nadwatu l-'izdiwājiyyati fil-lughati l-'arabiyya (Seminar on Arabic Diglossia), Amman, University of Jordan Press, pp. 25-36.

\section{APPENDIX}

\section{A. Orthographic translation errors}
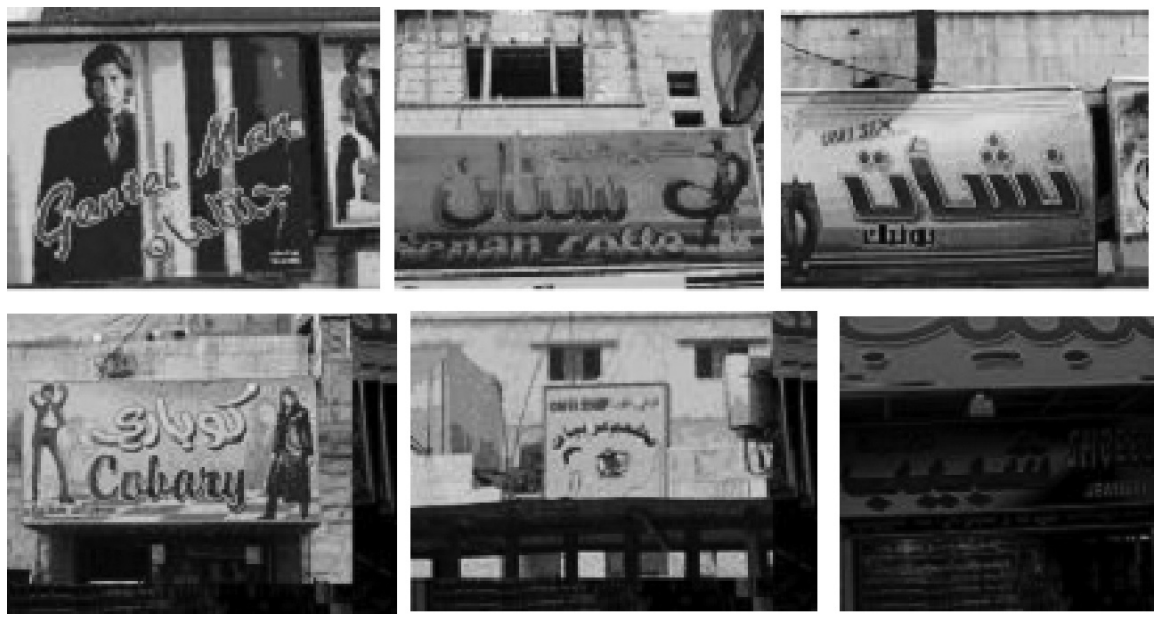

B. Translation Errors (Word order, Conceptual \& Informativity Errors)
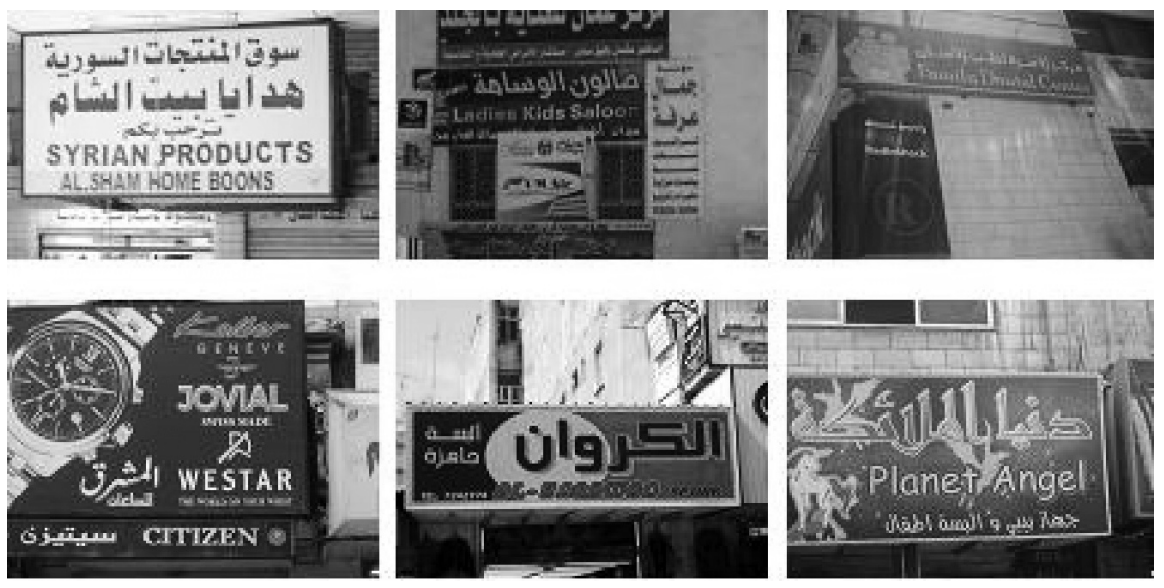
C. Transliteration Replacing Translation
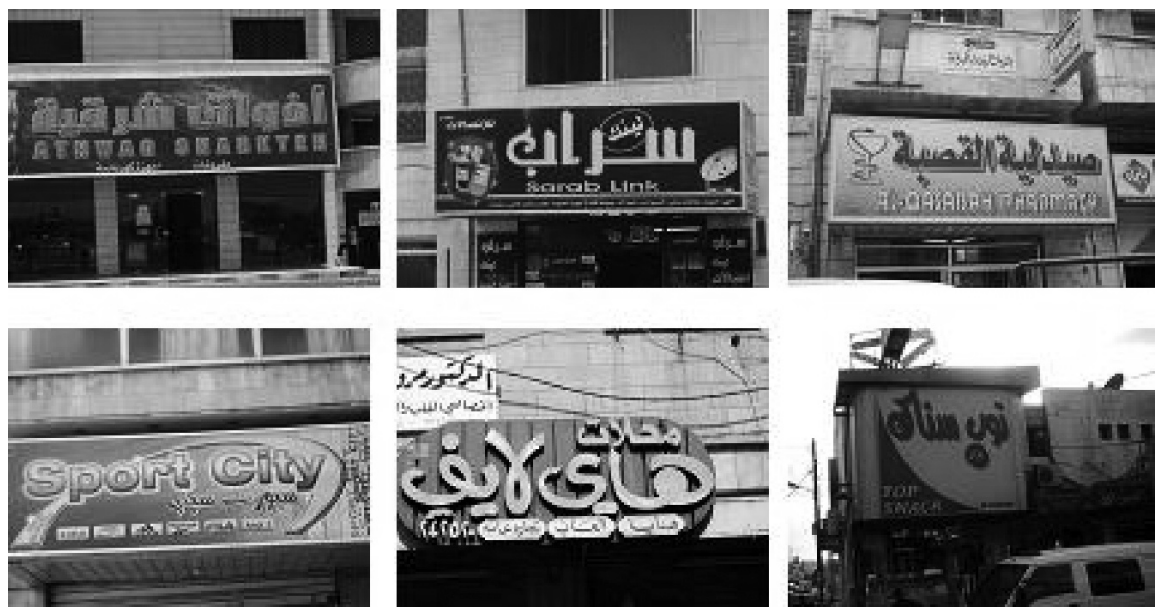

D. Total Avoidance via Foreignization
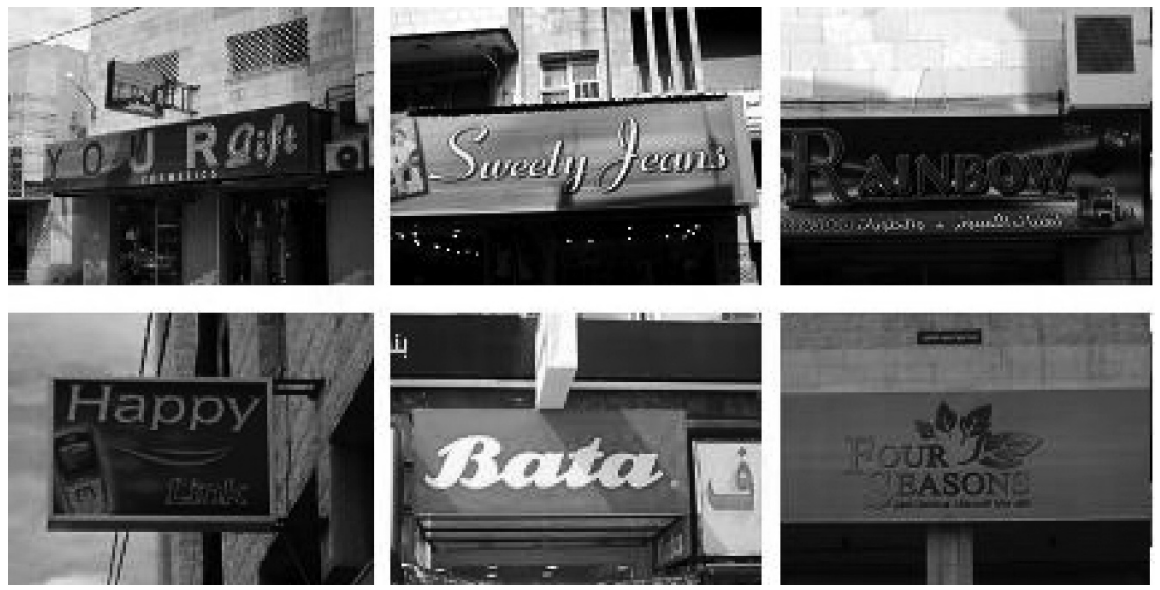